\title{
Local Examination and Research and Their Role in Iran Procedures
}

\author{
Behrooz Eslamifar ${ }^{1,2} \&$ Habib Asadi ${ }^{1,2}$ \\ ${ }^{1}$ Department of Law, Ardabil Science and Research Branch, Islamic Azad University, Ardabil, Iran \\ ${ }^{2}$ Department of Law, Ardabil Branch, Islamic Azad University, Ardabil, Iran \\ Correspondence: Habib Asadi, Department of Law, Ardabil Science and Research Branch, Islamic Azad \\ University, Ardabil, Iran.
}

Received: December 23, 2015 Accepted: January 15, 2016 Online Published: March 31, 2016

doi:10.5539/jpl.v9n2p26

URL: http://dx.doi.org/10.5539/jpl.v9n2p26

\begin{abstract}
Subject dictum time of its implementation should be notified to the parties and the absence of any of the parties to prevent the implementation of the dictum examination and research not local. If this dictum will be issued directly by the court or prosecutor's dictum to the plaintiffs in the case claim the cost of implementing each of the parties, the applicant is responsible. Dictum examination of the dictum of numbers. Namely the implementation of this dictum, the case will be ready and the court judgment cannot deviate from it. This dictum in legal proceedings (civil) real estate is noticed. However, sometimes the difference in movable property may also dictum examination of the issue. Tribunal to issue dictum examination site are free, and with the implementation of this dictum to obtain documentary evidence that a vote will be taken. Research and examination should be subject local place as soon as possible. The signs may be eliminated or reduced by intervening factors is access to witnesses. For research and examination local view must be subject to objective and precise touch and understand that if the meeting informed the parties that have signed and the judge and questioning is set. This dictum with which the parties have been notified of their appointment and the dictum to be implemented. It should be noted that in civil and criminal cases this has worked and convincing grounds for the prosecutor and the judge acquires and could make the dictum is the fact that the decision in this regard without any fact that it is right for violation.
\end{abstract}

Keywords: dictum, local examination, local research, circumstantial evidence, judge

\section{Introduction}

Expertism, examination, and research of all three of these are evidences that the Civil Procedure Code adopted in 1939 and 2000 and the Code of Criminal Procedure adopted in 2014 legislation along with other evidence of positive evidence on the proposed. Research examination, and the location one of the important reasons is that proof of claim of 248 to 256 of the Civil Procedure Code and the Code of Criminal Procedure Act of 2013, which is 123 to 167 judges and prosecutors respect the judicial of these materials and information on the quality and quantity of matter and to gain essential and above all persuasion and easily conscience decision to use them. Information from the obvious effects on the causes of transparency in the claims and in some cases makes it possible claim dictum and strength. Research local and examination Most of the time together both in local and in many cases are common to both the statements and the testimony of those who have information about the subject of dispute or claim is discovered and it must be visible and concrete in many cases because The judge obviously could not have all of expertise and knowledge required to expertism and assistance in the issue of judicial enforcement requires the presence of an affair in a decision that can be technical reasons credit ruling confirmed. The law of civil procedure, of 248 to 256 and 123 to 167 of the Code of Criminal Procedure for the examination and research local dedicated research and examination of the law of civil procedure not defined as local experts, it has been left to improvisation. But what is defined in Article 249 of this law dictum local research and not their definition of local (Madani, 2006). Local research is the nature of the testimony the witness can not not act as legal and not legal event, local research. For a local study, the first to study local courts and prosecutors dictum issue. This dictum although the introduction to the research community, but in turn has an introduction and it is that the parties or one of them (courts or prosecutors) are calling for local research, by resorting to this as proof of their own way. In this regard, Article 249 AH. D.M. Provides: If the parties or one of them rely on information from the site, although it is generally not mention the names of informants to the local court issued the dictum study (Hassanzadeh, 2005). Q.D.K Act of 2013 stipulates in Article 127: When research 
local and examination of witnesses and informants are also invited. The important point is that it is not necessary dictum in charge of the implementation of local research, the judge who issued the dictum is this. Article $250 \mathrm{AH}$ A. $\mathrm{Kr}$ declare (the implementation of local research dictum examination or by one of the judges of the court or the judge may be investigated except that on the court, examinations or local investigation, in which case you must implement these dictums the sentencing judge or a report done by someone trusted by the court, where a judge or magistrate to be persuasive.) The provisions of this Article shall be considered as local research may also be referred to as due to graduate in the case file and Because of the case file is as reliable. In both cases, the Court acts as his duty to find the truth. According to Article 251 AH. A. D. I must say that the local investigation a case file documents and written evidence must be recorded. It says: charge of the implementation of the dictum examination or investigation of local, face sessions and signed by the parties was aware of the purpose of the meeting (for parliament) dictum implementation of the examination or investigation of local (Dayani, 2009). Q.D.K in Article 129 of the Act of 2013: When research local and examination venue, all traces of visible and reveals that somehow it is effective, the magistrate ordered and collected by experts indicating be signed by persons involved in the issue.

On the other hand the Iranian legal system of the sentencing judge to two conditions dictum is documentary and scientific standard is the first of the two parties reached in proceedings and the organization and supervision. Therefore, the development of Judge observed in one of the most common examination subject of dispute is the title chosen for this action and add specified location because communication these observations show the location and constraints should not be interpreted and exclusive authority to see the issue in Court among the reasons why not. (Katuzian, 2011) for defining the examination location can be said that it is an official announcement about the presence of a person in a certain location and viewing the material things and the case file recording the work of writing the official in the fact sheet (Assembly Examination of the implementation of the dictum), so every place (space-space) (current occupation) left by the parties, and the examination is in place, we can be aware of the quality of this capture. So when the judge as a third party be present at a place, such as workshops, building and construction materials were dumped there, and the building will be done in circumstances where there can be observed, and the view of the leaves, The minutes of the execution of the written examination (Hayati, 2013) According to the said article 248 BC. A. D. D. About issuance dictum examination of the location, it can be considered as one of the evidences that the legislator of its relationship with the expert examination of a proof case is considered separately (Mohajeri, 2001).

Materials 125 and 128 .D.K 2013 till the examination and research local content is provided as follows. Article 125- examination and research location He was ordered by the local magistrate or justice is done by the bailiff. During the examination, those involved in the criminal can be present, but their absence prevented the examination is conducted.

Note: If the presence of the accused or other persons involved in the criminal matter when the necessary examination, shall be present at the orders of the magistrate.

Article 126. When research local and location examination, prosecutor necessary if personally present; but the offenses referred to in paragraph (a) of Article (302) of the Act, as well as an examination bodies, must be present in person as soon as possible.

Article 127 when research local and examination of witnesses and informants are also invited. In urgent cases, investigators may invite other persons to whom it is necessary to place it. If proven to be limited to statements of the persons mentioned in this article and they do not attend without reasonable excuse, the magistrate who issued the warrant, provided that their presence is necessary to identify the interrogator.

Article 128: Expert experts, such as doctors, pharmacists, engineers, and assessors when they are invited to comment on the specific information necessary.

Examination of nature as local research. The difference between the two is in how these two reasons in the written record local research, informants information is recorded, while in the examination of the location, physical work at the site of the crime scene on the left of the work done recorded. Thus we can say that the local investigation, citing statements by informants in a process of implementing local research dictum is recorded or the dictum accomplice who has been involved in the crime, while the examination of the location, what implementation dictum examination location is recorded, feeling and perception of officials and similarity to bear witness and doing it. However, the official witness stand and perform the (Shams, 2005). Considering the above, it is considered that that examination and the research community in the Iranian legal system are different from other reasons? It is hoped that an appropriate response in this regard should be provided. 


\section{Local Research}

248 to 256 of the Civil Procedure Code to the dictum examination and research location local dedicated and against the court may on its own motion or at the request of either of the parties dictum examination of the issue. This dictum and its implementation must be notified to the parties is possible. Dictum examination of the dictum of numbers, i.e. with the implementation of this dictum, the case is ready for judgment and the court can not deviate from it. This dictum is often issued in cases where the claim is found immovable property. However, sometimes the difference in movable property may also dictum examination of the issue. The court issued a dictum free examination of the implementation of this dictum to obtain documentary evidence which will dictum decision is made. In the new D.K of 123 till 167 of this issue.

\section{Compare Research Local and Examination Site}

If your court or at the request of a party, examination Place it deems necessary, dictum The so-called issue dictum examination Location, including dictum research (Matin Daftarri, 2009; Madani, 2006).

For example, one of the ownership of a plot of land between his property and the property is located next door, he is different. The plaintiff claims that the land within the boundaries of his property and the other side denied this claim. Court to determine the validity of the case, can dictum examination local Issued. Then go to the place of registration and records with respect to adjacent property, determines that the disputed piece of land, the property is within one of the two. After mapping the location and attach it to the court case will proceed to sentencing (Sadrzadeh Afshar, 2000). However, dictum research local, a judge or enforcement dictum The location and obtaining information from informants and witnesses, the applicant claims research Check and proceed to sentencing (ibid, p. 241). Or, for example, damage to the wall and the plaintiff sought examination In this case, the second site visit and the statements of informants as listening to the truth is discovered.

\section{Comparing Local Research, Witnesses}

Difference research local and hear the testimony of a witness in the testimony of the senses is a result of seeing that is directly seen or heard. While research local to inform the people that depend on more than indirectly due to proximity with the subject of the dispute, as received material (Madani, 2006). Therefore, research local, those of them research It is also seen and heard, direct and indirect, have also expressed their impressions (Shams, 2005).

\section{Local Research and Testimony}

Research local only circumstantial evidence and an independent judicial proof is not the case. Information from place of business is a subject of dispute. For this reason the Code of Civil Procedure provisions in Articles 249 to 256 has been announced. Research local it is certified in common with both of these reasons, the statements of those who are on the subject of dispute, listening (Mohajeri, Description of the Procedure Madani. 2006).

\section{Court Proceedings after the Implementation of the Dictum Examination}

Contrary to the provisions of Article 439 of the old QDM under Article 35 bill amending Act (1979) set up a public court hearing after the implementation of the dictum examination the local authority. The final part of the article: "... Also on the dictum research and examination of the file and run it whenever the decision is mine. The court can proceed to judgment without specifying any other meeting." The new law also set a hearing session after the implementation of the dictum unforeseen and therefore, if a case is ready to issue a final decision, the court will proceed. Although this would speed up the procedure, but in practice, the right to protest a meeting of the parties to comment and even violated its examination of the site. In particular party for any reason dictum is not present in the implementation of the. Therefore, according to the provisions of the final part of the answer is that the opportunity to explain or demonstrate potential for court sessions to the dictum that party dictum.

\section{Court Proceedings after the Implementation of the Dictum Research Local}

As court proceedings after the implementation of the dictum after performing the examination described dictum research local, meeting the requirements despite court hearing is not required to read the minutes of the examination at the hearing to the parties to make oral explanations of it. However, pursuant to Article 35 of the bill amending legislation (1979) and an optional public trial after the trial run according to the dictum and the final part of this article that the issue dictum research and examination of the file and run it when judgment is mine, another court can proceed to judgment without specifying the meeting. The new law also determines the meeting's proceedings after the implementation of the dictum unforeseen. This method, however, the speed of the proceedings and the judgment can be effective, but in practice, the right to protest a meeting of the parties to explain and even (which is probably For some reason, incomplete or obscure) destroyed especially is However 
due to the implementation of the dictum is not present. Therefore, with regard to the concept if not ready Q.A.D.M against the end of the article 35 case after the implementation of the dictum research local to issue after the implementation of the dictum, the court can not vote results in effective and better opportunity to explain or protest again possible for the parties to provide sessions dictum.

\section{Conditions and Control Features}

The "155" Q.D.M says in cases where the judge cited the testimony of a witness as a religious reason, it is necessary to control with the following conditions:

1. 2. Reason 3. Faith 4. Puberty purity 5- 6- Justice saw no personal benefit to control or eliminate loss of his worldly 7 . The lack of animosity between the witness and the parties 8 . The unemployment and the tramp begging

\section{Local Examination Contradiction with Documents}

It seems that the conflict between the two should be avoided, with the explanation that attributes any mention of the subject of dispute in the document, only true and false claims that are completed in other words, the presence or absence have to go through expertism or examination Location to be confirmed, it itself has no authority to authenticate documents or false under their attributes. For example, if you type in the document indicating the subject of the transaction silver silver later on whether the dispute is achieved, it can not be proved on the basis of its own silver document and the document is the lack of the authority of but also for the determination of silver or lack of it, the matter should be referred to expert. The same is true of other attributes and conditions and therefore, to prove the claim false attributes in the document, as the case may be dictum expertism or examination Place issued. The judge, according to the result examination the claims stated in the document with false and accordingly continues to handle.

\section{Local Examination Contradiction with Witness}

Conflicting testimony of witnesses with the examination of the specific means if there is evidence that the issue is still visible or understood by other senses. For example, if the architect was called witnesses to testify weakness and ruin the wall and the wall is called evil, corruption, through the examination site can be viewed directly on the wall and see if you judge the walls well, in this case, false testimony from Place proven through examination and therefore there is no testimony to be inconsistent with the examination location. Therefore, if the issue of martyrdom is still visible and seen, through direct observation magistrate could prove false witnesses and the results of the examination will proceed to sentencing. Even if such cases are believed to disprove false testimony, however, the final call to action based on the results of the examination is the difference will not be achieved. Because it is the result of the testimony of witnesses and the examination of the conflict can be achieved and what the judge saw the witnesses will be first. Prior knowledge of examination of the witnesses in such cases are not in violation of Article 241 but who recognize the value and impact Q.D.M certificate with the court knows, is a confirmation of this view.

\section{Local Examination Contradiction with Expertism}

Examination of the conflict must be stated expertism place with one hand due to the specialized nature of the subject expertism is essentially out of the ability to judge, and also with regard to examination of that aspect of the examination should be specialized. The assumption based conflict between the evidence is not there. Issued a dictum Technical expertism with the subject, can not be straight on the same subject through the examination of the surgical site.

\section{Conditions and Control Features}

The "155" Q.D.M says in cases where the judge cited the testimony of a witness as a religious reason, it is necessary to control with the following conditions:

1. 2. Reason 3. Faith 4. Puberty purity 5- 6- Justice saw no personal benefit to control or eliminate loss of his worldly 7 . The lack of animosity between the witness and the parties 8 . The unemployment and the tramp begging.

\section{Local Examination Contradiction with Documents}

It seems that the conflict between the two should be avoided, with the explanation that attributes any mention of the subject of dispute in the document, only true and false claims that are completed in other words, the presence or absence have to go through expertism or examination Location to be confirmed, it itself has no authority to authenticate documents or false under their attributes. For example, if you type in the document indicating the subject of the transaction silver silver later on whether the dispute is achieved, it can not be proved on the basis 
of its own silver document and the document is the lack of the authority of but also for the determination of silver or lack of it, the matter should be referred to expert. The same is true of other attributes and conditions and therefore, to prove the claim false attributes in the document, as the case may be dictum expertism or examination Place issued. The judge, according to the result examination the claims stated in the document with false and accordingly continues to handle.

\section{Local Examination Contradiction with Witness}

Conflicting testimony of witnesses with the examination of the specific means if there is evidence that the issue is still visible or understood by other senses. For example, if the architect was called witnesses to testify weakness and ruin the wall and the wall is called evil, corruption, through the examination site can be viewed directly on the wall and see if you judge the walls well, in this case, false testimony from Place proven through examination and therefore there is no testimony to be inconsistent with the examination location. Therefore, if the issue of martyrdom is still visible and seen, through direct observation magistrate could prove false witnesses and the results of the examination will proceed to sentencing. Even if such cases are believed to disprove false testimony, however, the final call to action based on the results of the examination is the difference will not be achieved. Because it is the result of the testimony of witnesses and the examination of the conflict can be achieved and what the judge saw the witnesses will be first. Prior knowledge of examination of the witnesses in such cases are not in violation of Article 241 but who recognize the value and impact Q.D.M certificate with the court knows, is a confirmation of this view.

\section{Local Examination Contradiction with Expertism}

Examination of the conflict must be stated expertism place with one hand due to the specialized nature of the subject expertism is essentially out of the ability to judge, and also with regard to examination of that aspect of the examination should be specialized. The assumption based conflict between the evidence is not there. Issued a dictum Technical expertism with the subject, can not be straight on the same subject through the examination of the surgical site.

Article 149 of the Civil Procedure Code in this case states that: "In cases where interested parties the possibility that in the future such as research and examination of evidence in their case local inquiries and information from informants and experts offices of circumstantial evidence in place and the reasons why the party or another, it will be impossible or can ask the court to provide them themselves. In order to provide for the registration and operation of these reasons is just for consideration and recognition of their value in use by the court.

Collect reason, freedom and respect for the rights of individuals, is an integral part of the investigation and hearing process. Why is Islam that emphasizes respect for individual liberty and all the democracies in the world, any reason that the free will of the person offended, understand and adhere to the presumption of innocence void in all legal systems in the world, because of the importance of true satisfaction is. Due to their professionalism and fraud offenders with crimes of scientific discovery that will require, of course, the necessity of restoring the judicial police. The presumption of innocence is an inviolable principle that must be considered. Research and examination of the process of gathering evidences is that it judges necessary for the fulfillment of the mandate to research and examination local magistrate or judge to issue or enforcement by expert to discover the reality and the truth is used. Research local cases in Islam are of high importance to individual rights should not be violated. Because in Islam to make the right judgment and justice among the people, recommending that the Prophet (PBUH), Imam Ali (as) and Imam attention to this issue with your research and use the necessary examination and experts There are many witnesses on the subject of the claim. 248 to 256 of the Code of Civil Procedure and the Code of Criminal Procedure of 123 to 167 and other related materials to supply expertism for justice and truth, and to obtain evidence to convince the judge that the court can issue goes at the request of any of the parties may directly or dictum examination and research local issued and testimony that is effective in some cases are invited. Shall be communicated to the parties before the dictum time and the absence of any dictum will not hamper the implementation of necessary equipment cost and even cost expertism want dictum should provide and pay. If you do not prepare their petition will be rejected in the first instance and in the appeal stopped. In some cases, a magistrate or judge is seen to directly refer to the location or, if necessary, using subject matter experts to review and, if meeting the sign set. The dictum is generally ready for decision and should be issued as soon as possible because this dictum may be lost or changed their works and sometimes in cases that resulted in deprivation of life by the investigator to the site visit Doctors or Engineers Certified This technical aspects of uses and must comply with law enforcement justice all the predictions that long and detailed discussion of how audit and non-financial damage to the occupants and the damage who should damage compensation is discussed at the end, but the goal is that the dictum conditions and the presence of witnesses and 
participants in the implementation of the dictum is very important. If your implementation of the dictum and research outside the court, the court can ask the court to enforce dictum and it is a reliable court. Because the dictum that the implementation of these exceptions outside of the jurisdiction made by the sentencing judge. That each party to the other provisions of mayhem informants can testify, refuses. It is also true that the same material witness rejected. That the information obtained by the Justice Statistics and the knowledge or confidence it is effective. Located to explore and clarify the implementation of the dictum is necessary and usually takes a day and those who are involved in the issue of the judge's order without reasonable excuse will be attracted. And their absence did not hinder the implementation of the dictum. The examination bodies should remember that the investigator is required to attend in person as soon as possible and by groups (including forensic experts, detectives, police officers) all traces of visible and that somehow included in the case by order of magistrate Law enforcement to collect and audio session will be listed and numbered and must work to maintain the convertible, photographed, filmed and done according to the judge and the crime scene surrounded by appropriate means and the arrival of the exit at the prevent and seals, to be dispensed with. Should remember that the audit, the scope and authority, number and time of arrival, and protect the rights and dignity of persons below the levels of care and maintenance of property damage while corrupt lack of respect for the legal and policing inspection and possess fully comply with witnesses who otherwise should compensate the material damage has been compiled and is usually compensated by the government and state who is to blame.

\section{Reference}

Ashori, M. (2009). Code of Criminal Procedure, Tehran, the publisher, 1388, Eighth Edition, vol. 2, p. 114.

Diani, A. R. (2006). Civic evidences in criminal matters, publications, teaching, Tehran, first edition.

Gholdost koibari, R. (2007). General Code of Criminal Procedure, Tehran, woods, second edition, 1386, p. 63.

Hayati, A. S. (2013). Civil Procedure in the current legal order, third, Tehran.

Katuzian, N. (2011). proof and evidence (vol. 2,6th ed.). Tehran.

Madani, S. J. (2006). Evidence stable release, Tehran, ninth edition.

Matin Daftarri, A. (2009). Civil procedure and commercial printing of Tehran University, Third Edition, Vol. 3.

Mohajeri, A. (2001). Description of the Code of Civil Procedure the Public and Revolutionary Courts, The Treasure of Knowledge, Tehran, first edition, Vol. 2.

Sadrzadeh Afsha, S. M. (2000). Business Code of Civil Procedure and the General and Revolutionary Courts, Fifth Edition, published by the Institute of SID (Majid), Tehran.

Shams, A. (2005). Code of Civil Procedure, The Drake, Sixth Edition.

\section{Copyrights}

Copyright for this article is retained by the author(s), with first publication rights granted to the journal.

This is an open-access article distributed under the terms and conditions of the Creative Commons Attribution license (http://creativecommons.org/licenses/by/3.0/). 